\title{
TWO BRIEF HISTORICAL NOTES
}

\author{
BY J. G. MYERS
}

Imperial College of Tropical Agriculture, Trinidad, B. W. I.

I. The Oldest Work on Insect ANATomy

In the first volume of Bodenheimer's monumental history of entomology appears the following statement ( $p$. 327): "Als das älteste Werk anatomischer InsektenBetrachtung gilt das Apiarium des römischen Arztes Francesco Stelluti (1625)."

Bodenheimer seems entirely to have overlooked the great anatomist, Giulio Casserio (Casserius), the successor of Fabricius ab Aquapendente in the Chair of Anatomy and Physics at Padua.

Although, so far as we know, Casserius published no separate works on insect anatomy, yet his descriptions and dissections of cicada anatomy, printed in 1600, are so excellent and faithful that it seems to us that his distinction as the first insect anatomist is indisputable. Several accounts of cicada structure appearing in the present century have been less accurate. The general treatise in which his studies are buried is entitled: De vocis auditusque organis historia anatomice singulari fide methode ac industria concinnata tractatibus duobus explicata ac variis iconibus aere excusis. (Ferrara, F. 2 tractatus in 1 vol. Tab. I-XXII.et I-XII).

\section{ZOOPROPHYLAXIS FOR MOSQUITOES}

In view of the present emphasis placed by Roubaud and other workers on the protection from Anophelines, said to be afforded to man by the vicinity of domestic animals in large numbers, it is interesting to notice that Humboldt was apparently the first to remark on this and to describe an instance in which the theory was deliberately put into practice. In his "Personal Narrative" (Ross trans., 1852, vol. II, p. 280) he says, "In the villages of the Rio Magdalena the Indians often invited us to stretch ourselves as they did on ox-skins, near the church, in the middle of the plaza grande, where they had had assembled all the cows in the neighborhood. The proximity of cattle gives some repose to man." 

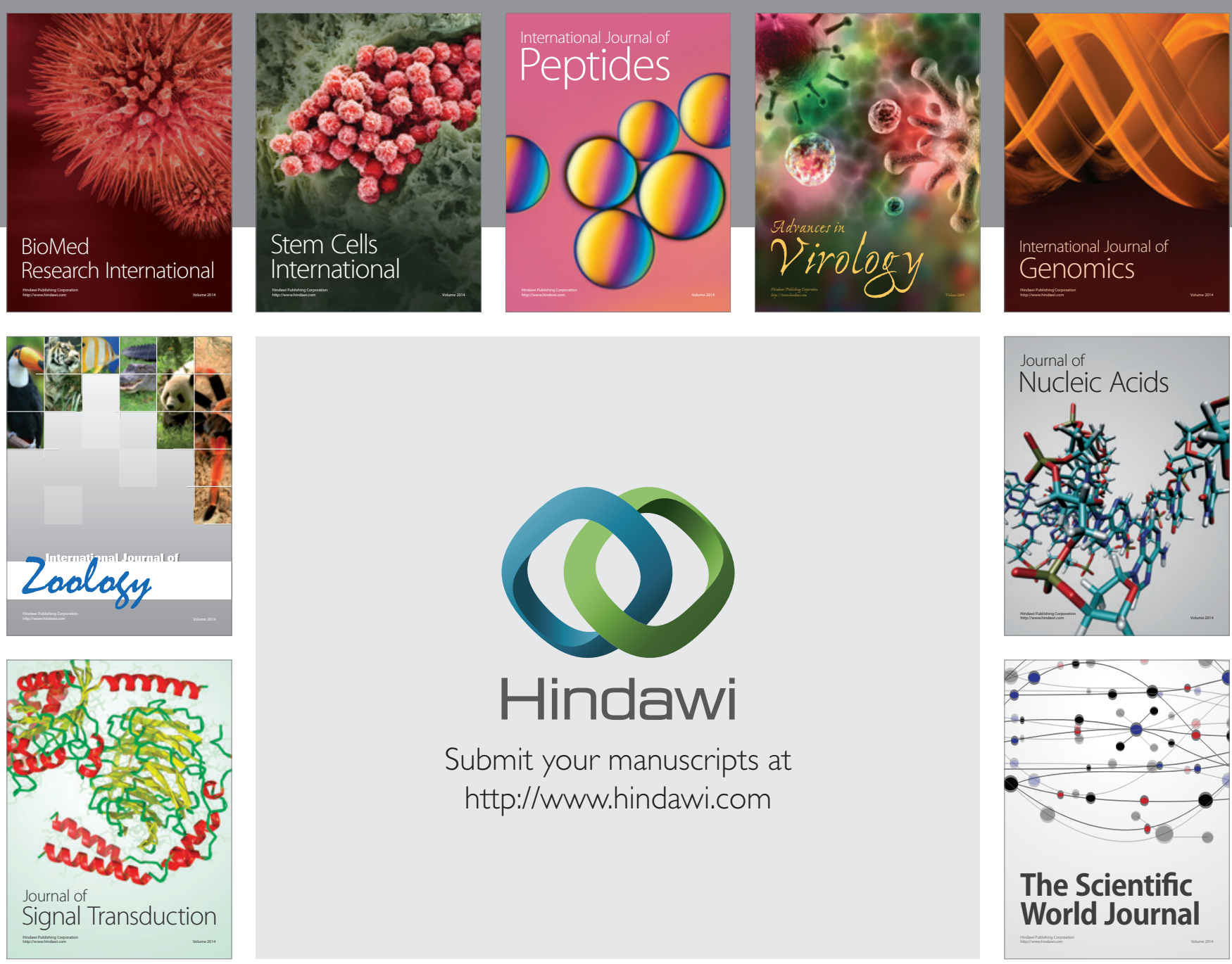

Submit your manuscripts at

http://www.hindawi.com
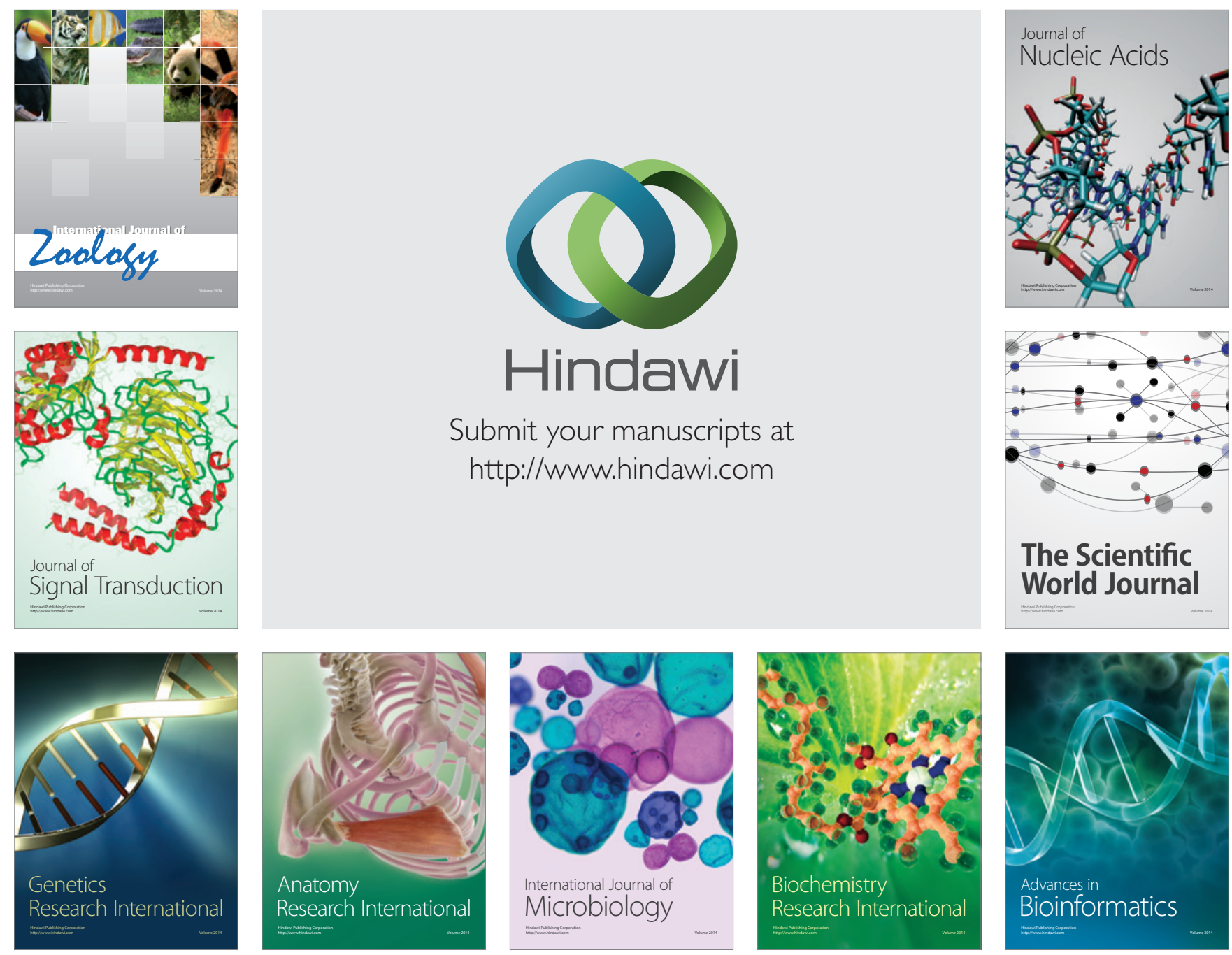

The Scientific World Journal
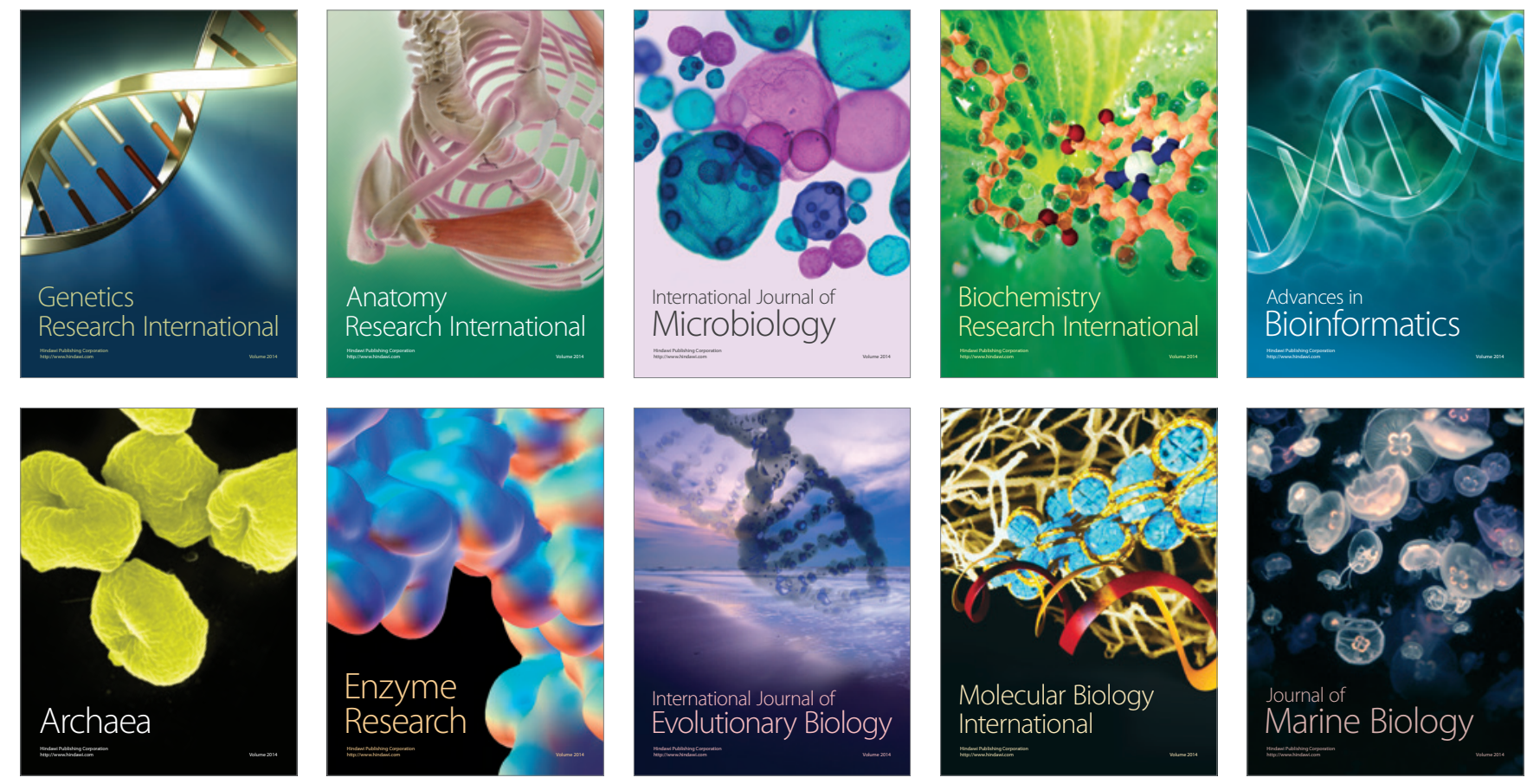